\title{
FLUXO COMERCIAL DA CELULOSE BRASILEIRA PARA O BRASIL, RÚSSIA, ÍNDIA, CHINA E ÁFRICA DO SUL (BRICS), 1990 A 2016
}

\author{
Letícia Soares Viana ${ }^{1}$ \\ Naisy Silva Soares \\ Lyvia Julienne Sousa Rego
}

Resumo: O presente trabalho analisou o fluxo de comércio do segmento brasileiro de celulose antes e depois da formação do BRICS. Para tanto, foram estimados os índices de Intensidade de Comércio (IIC), de Orientação regional das exportações (IOR), de Grubel e Lloyd (GL) e de Menon e Dixon. Os resultados indicaram que o padrão de comércio neste setor, se mostrou como interindustrial, houve aumento na intensidade de comércio entre os países-membros dos BRICS após sua formação e as relações comerciais apresentaram-se voltadas para o bloco.

Palavras-chave: Intensidade do comércio. Orientação Regional. Bloco Econômico.

\section{COMMERCIAL FLOW OF BRAZILIAN CELLULOSE TO BRAZIL, RUSSIA, INDIA, CHINA AND SOUTH AFRICA (BRICS), 1990 TO 2016}

Abstract: This study analyzed the trade flows of the Brazilian cellulose segment before and after the formation of the BRICS. For this purpose, the Trade Intensity, Regional Export Orientation, Grubel and Lloyd and Menon and Dixon indices were estimated. The results indicated that the pattern of trade in this sector was shown to be interindustry, there was an increase in the intensity of trade between the member countries of BRICS after its formation and trade relations were turned towards the bloc.

Keywords: Intensity of trade. Regional Orientation. Economic Blocs.

\section{FLUJO COMERCIAL DE LA CELULOSA BRASILEÑA A BRASIL, RUSIA, INDIA, CHINA Y SUDÁFRICA (BRICS), 1990 A 2016}

Resumen: El presente trabajo analizó el flujo de comercio en el segmento de celulosa brasileña antes y después de la formación de los BRICS. Para este propósito,se estimaron los índicese Intensidad Comercial, Orientación a la Exporta ción Regional, Grubel y Lloyd y Menon y Dixon. Los resultados indicaron que el patrón de comercio en este sector demostró ser interindustrial, hubo un aumento en la intensidad del comercioentre los países mie mbros del BRICS después de su formación y las relaciones comerciales se volvier on hacia el bloque.

\footnotetext{
1 Universidade Estadual de Santa Cruz, Departamento de Ciências Econômicas, Ilhéus, Brasil, leticiasoaresviana@hotmail.com, https://orcid.org/0000000283979298

2 Universidade Estadual de Santa Cruz, Departamento de Ciências Econômicas, Ilhéus, Brasil, naisysilva@yahoo.com.br, https://orcid.org/0000-0001-6855-0218

3 Universidade Federal do Sul da Bahia, Ilhéus, Brasil, Centro de Formação em Ciências Agroflorestais, lyviajulienne@hotmail.com, https://orcid.org/0000-0001-7043-6860
} 
Palabras clave: Segmento de celulosa. Intensidad del comercio. Economia internacional.

\section{Introdução}

Em 2001, o economista Jim O'Neill destacou em um relatório para um dos maiores bancos de investimentos, Goldman Sachs, que países como Brasil, Rússia, Índia e China apresentavam um elevado crescimento econômico e que poderiam superar os países ricos até 2050. Assim sendo, uma nova congregação se conciliava em busca de interesses comuns e de maior representatividade no panorama mundial. Entretanto, apenas em 2009 que o grupo se consolidou como uma aliança política, e dois anos depois, em 2011, contou com a entrada da África do Sul, sendo representada pela letra $S$ do inglês South Africa formando o conhecido BRICS.

Todos os anos, os cinco países se reúnem, através de cúpulas, para debaterem e definirem acordos e medidas consideradas relevantes. Mesmo possuindo características em comum, estes países não compõem um bloco econômico, e sim uma aliança representada pelos índices de desenvolvimentos parecidos e com intuito de ganharem força no cenário global, pois apesar do real interesse em se tornarem um bloco, a relação comercial entre eles ainda está em um estágio inicial com integrações limitadas. Além disso, não existem planos para concretizar a criação, de fato, de um bloco econômico, contudo, o interesse político em conformidade funciona como uma alavanca para uma atuação global destes países, fortalecendo o grupo, tornando-os como atores estratégicos e representantes da economia emergente (Oliver Stuenkel, 2017).

O BRICS, diferente da maioria dos blocos econômicos, não dispõe de uma organização bem definida e idealizada, assim, há várias questões que põe em dúvida sua consolidação no âmbito global. Entretanto, há também, argumentos otimistas que justifiquem essa possibilidade. Como aquela que estima, em pouco tempo, a superação em importância, da maior economia atual, os Estados Unidos. E como relata Baumann (2015), "isso as transforma não apenas em potências econômicas, mas também em agentes ativos no processo de definição das políticas globais".

Somado a isso, outros números sinalizam o desempenho desse grupo frente ao mercado internacional. Os BRICS representam $46 \%$ da população e um Produto Interno Bruto (PIB) nominal de US\$16,92 trilhões, o que equivale a 23,1\% 
do PIB mundial. Em 2014, as importações mundiais somaram US\$3,03 trilhões, enquanto as exportações totalizaram mais de US\$3,4 trilhões, naquele mesmo ano e a estimativa é que esta representação cresça ainda mais, já que em 2001, o grupo representava $8,1 \%$ do total das exportações mundiais, e em 2015, este número alcançou $19,1 \%$ do total.

No que diz respeito à importância do BRICS para o Brasil, de acordo com Ministério das Relações Exteriores (2015), entre 2006 e 2015, o comércio intraBRICS cresceu 163\%, passando de US\$ 93 para 244 bilhões, no total faturado, só as exportações do Brasil para os demais países do BRICS aumentaram 202\%, ou seja, houve uma elevação de US\$14,25 para 43,05 bilhões, e as importações tiveram incremento de $249 \%$, passando de US $\$ 10,84$ para US $\$ 37,87$ bilhões, neste mesmo período.

A título de comparação, segundo Palácio do Planalto (2018), o Mercosul acumula um crescimento na balança comercial entre seus membros de mais de 12 vezes: de US $\$ 4,5$ bilhões no ano de sua criação, 1991, para US\$ 59,4 bilhões em 2013. Entre os anos de 2009 e 2014 as exportações brasileiras para os paísesmembros do bloco cresceram apenas $29,01 \%$ passando de US $\$ 15,82$ para US\$ 20,42 bilhões, enquanto as importações aumentaram de US $\$ 13,10$ para US $\$$ 17,24 bilhões neste mesmo período.

Dado isso, o BRICS vem ganhando papel de destaque no meio das pesquisas, principalmente aquelas acadêmicas que buscam entender sobre o cenário político-econômico internacional e a capacidade de países emergentes ampliarem sua atuação no cenário global. Entretanto, há uma escassez de pesquisas sobre o desempenho das exportações brasileiras para o BRICS, principalmente com a celulose, cujo segmento está em franco crescimento no país. Segundo as informações do Ministério da Indústria, Comércio Exterior e Serviços (MDIC, 2018), dentre os dez principais produtos brasileiros exportados para o mundo, sete deles são produtos agrícolas, sendo estes a soja em grão, a carne de frango, o açúcar bruto, a celulose, o farelo de soja, carne bovina e o café em grão.

Seguindo o mesmo padrão brasileiro, todos os demais países-membros dos BRICS se destacam pelo desempenho do setor primário. Segundo a Associação Brasileira de Celulose e Papel (BRACELPA, 2015), em 2012 a China era a 
segunda maior exportadora de celulose, o Brasil era o quarto, a Rússia a oitava e a Índia a décima primeira.

O setor de papel e celulose é qualificado por dois segmentos distintos dentro da pauta de exportações brasileiras, no qual de um lado encontra-se o papel com uma gama vasta de diferenciação de produtos e do outro, a exportação de celulose, caracterizada pela commodity de pasta química de madeira. No primeiro mercado, apesar dos produtos possuírem características próximas entre si, eles não são homogêneos, fazendo com que cada país ganhe destaque em sua determinada produção, além de tornar o produto mais competitivo já que os países importadores têm a opção de escolher não apenas pelo preço, mas também pelas características distintas de cada. Já no segundo mercado, os produtos são vendidos de forma homogênea em todos os países, tendo o seu diferencial no preço de venda (GUIMARÃES, 2007).

De acordo com o "Guia do Panorama Setorial - Celulose e papel 2016/2017" realizado pela Poyry Tecnologia Ltda., entre os anos de 2000 a 2015, o setor de papel no Brasil cresceu 2,5\% ao ano, sendo que em 2015 a produção brasileira foi de 10,4 milhões de toneladas, dando destaque para a fabricação de papéis para embalagens e sanitários - este último devido ao número crescente de pessoas saindo da pobreza absoluta. Neste mesmo ano, o total das vendas externas foi de 2.021 milhões de dólares. Já no mercado especificamente da celulose, estima-se que o consumo mundial até 2030 cresça em média 1,1\% ao ano, com notoriedade para os países emergentes. No Brasil, dentre a produção de celulose, cerca de 50\% eram destinados à exportação, já em 2015 esse número cresceu para $70 \%$, dando uma média de crescimento na produção de $5,9 \%$ ao ano.

Segundo os dados do Departamento de Pesquisas e Estudos Econômicos (DEPEC) - Bradesco, no ano de 2016 o Brasil ultrapassou a China e o Canadá, e se tornou o segundo maior produtor de celulose mundial, ficando atrás apenas dos Estados Unidos, além de ocupar a oitava posição no ranking mundial de produção de papel.

Em 2016, a produção nacional chegou a quase 19 milhões de toneladas, a produção de papel no mesmo período esteve em torno de 10 milhões (Figura 1). 0 mesmo ocorreu com as exportações, que obteve números ainda mais expressivos com diferenças ainda maiores, já que no mesmo ano, o volume exportado de 
celulose alcançou quase 12 milhões de toneladas, entretanto, na mesma época a exportação de papel chegou em apenas 2 milhões (Figura 2).

Ambas as frações apresentam crescimento expressivo em detrimento das escalas de produção, da quantidade e qualidade dos recursos naturais disponíveis e ainda da tecnologia investida gradativamente, contudo, é importante ressaltar que o segmento da celulose vem conferindo, de fato, um saldo positivo e significante para a balança comercial (GUIMARÃES, 2007, p. 12).

Figura 1 - Produção nacional de papel e celulose em toneladas, de 1994 a 2016

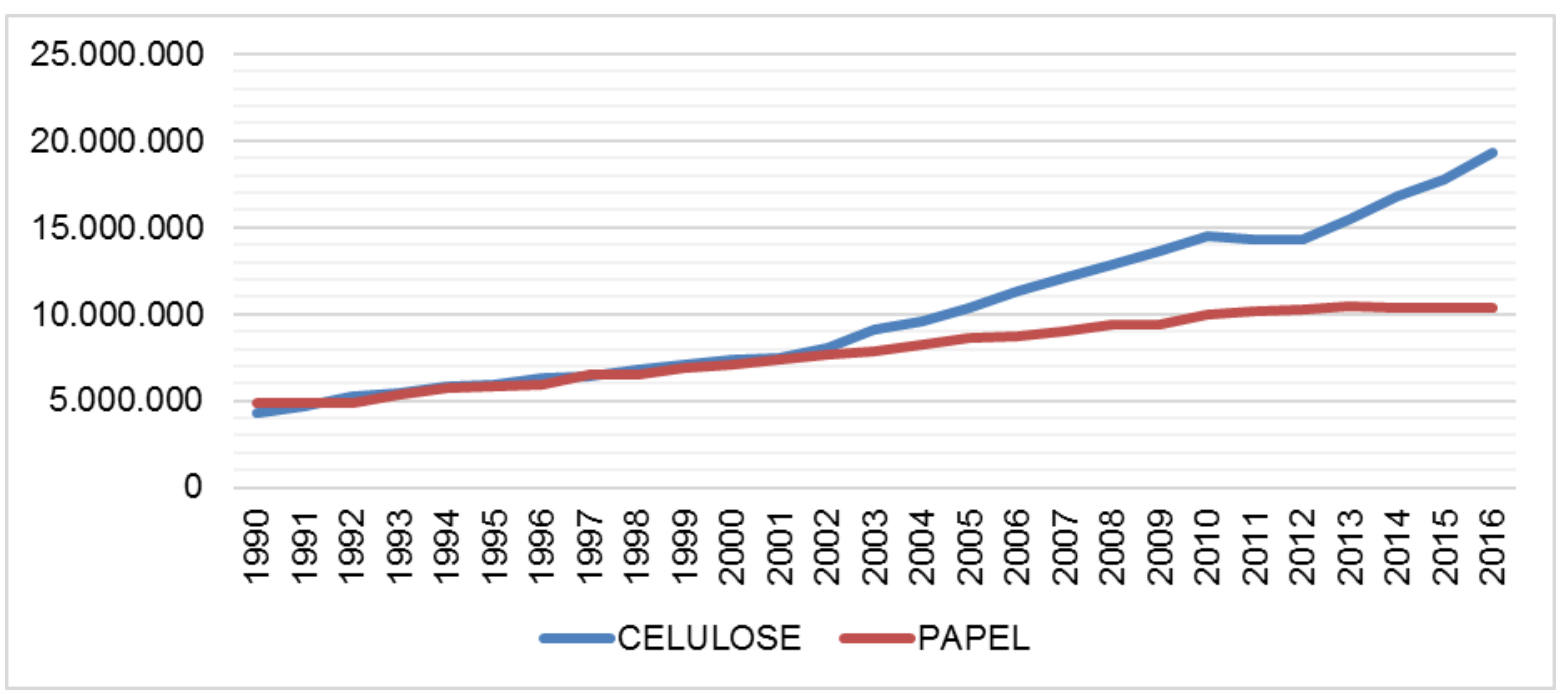

Fonte: Elaborada pela autora a partir de dados da FAO (2017).

Figura 2 - Exportação nacional de papel e celulose em milhões de toneladas, de 1994 a 2016

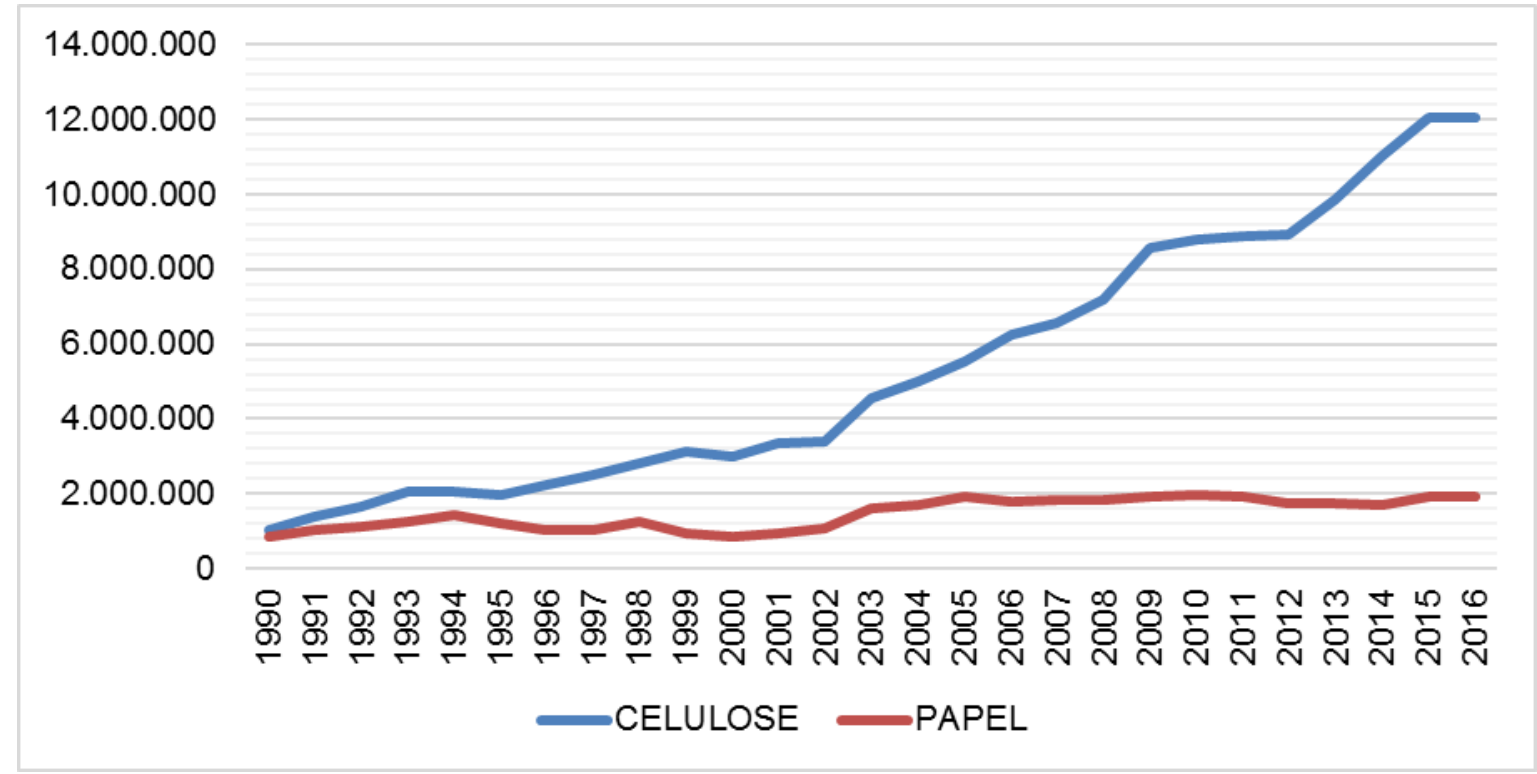

Fonte: Elaborada pela autora a partir de dados da FAO (2017). 
Nesse contexto, mediante os valores expressivos da celulose frente ao papel, justifica-se a escolha da execução deste trabalho que tem como proposta analisar o desempenho brasileiro nos BRICS na comercialização do segmento da celulose, commodity comum a todos os países-membros e questiona-se, houve crescimento do comércio da celulose brasileira depois da formação do BRICS?

Posto isto, essa pesquisa poderá contribuir para a implementação de políticas voltadas para o setor bem como estimular as exportações e reduzir as importações brasileiras, contribuindo para o desenvolvimento das regiões em que atua e ainda reforçar a importância do mesmo para os BRICS, auxiliando os agentes ligados ao setor na tomada de decisão sobre produção e comercialização.

Sendo assim, o objetivo geral dessa pesquisa foi analisar o fluxo de comércio da celulose brasileira antes e depois da formação do BRICS, de 1990 a 2015.

Especificamente, pretendeu-se analisar a orientação e a intensidade das exportações brasileiras do segmento de celulose antes e depois da formação do BRICS, bem como avaliar a evolução do comércio intra-indústria e interindústria no segmento de celulose.

\section{Aspectos Conjunturais do BRICS}

Os países que formam os BRICS se diferem muito nas trajetórias históricas, nos costumes culturais e até nos objetivos econômicos, entretanto, são nações que compartilham características importantes em relação ao restante do mundo, como área territorial, população, total arrecadado do Produto Interno Bruto (PIB) e até o Índice de Desenvolvimento Humano (IDH), como apresenta a Tabela 1.

Tabela 1 - Informações gerais dos países pertencentes aos BRICS, em 2015

\begin{tabular}{lcccc}
\hline & $\begin{array}{c}\text { Dimensão Geográfic } \\
\left(\mathbf{k m}^{2}\right)\end{array}$ & $\begin{array}{c}\text { População } \\
\text { (milhões) }\end{array}$ & $\begin{array}{c}\text { PIB (USD) } \\
\text { (bilhões) }\end{array}$ & IDH $^{*}$ \\
\hline Brasil & 8.516 .000 & 206 & 1.804 & 0,775 \\
Rússia & 17.100 .000 & 144 & 1.366 & 0,798 \\
Índia & 3.287 .000 & 1.309 & 2.112 & 0,609 \\
China & 9.597 .000 & 1.371 & 11.060 & 0,727 \\
África do & 1.220 .000 & 55 & 317,4 & 0,660 \\
Sul & & & &
\end{tabular}

Fonte: Elaborada pela autora a partir de dados do Banco Mundial e Programa das Nações Unidas para o Desenvolvimento (PNUD). * valores referentes ao ano de 2014. 
De acordo com um ranking promovido pela Central Intelligence Agency (CIA), que compara a dimensão geográfica dos países, Rússia, China, Brasil, Índia e África do Sul, estão entre os 30 maiores - que possuem mais de $1000.000 \mathrm{~km}^{2}$ e ocupam, respectivamente, as posições $1^{\circ}, 4^{\circ}, 5^{\circ}, 7^{\circ}$ e $25^{\circ}$. O mesmo ocorre com suas populações que também se apresentam entre as maiores do mundo. Nesta mesma pesquisa, em $1^{\circ}$ lugar está China seguida pela Rússia na $2^{2}$ colocação, o Brasil na $5^{\underline{a}}$ posição e Índia e África do Sul ocupando o $7^{\circ}$ e $25^{\circ}$ lugar. Isso corresponde a $26 \%$ da área do planeta e $46 \%$ da população mundial.

O PIB dos países constituintes dos BRICS também merece destaque. O Instituto de Pesquisa das Relações Internacionais listou as 15 maiores economias do mundo, conforme o PIB do ano de 2016 e entre elas apresenta China em segundo lugar - atrás apenas dos EUA-, Índia em sétimo, Brasil em nono e Rússia ocupando a décima segunda colocação. Os BRICS, com exceção da África do Sul, dividem o ranking com outras grandes economias como Alemanha, Reino Unido e França, e juntos compartilham mais de $20 \%$ do PIB mundial.

De acordo com os dados da PNUD (2015), ao que se refere ao Índice de Desenvolvimento Humano é possível notar também certa aproximação já que Rússia, Brasil e China são considerados países de alto desenvolvimento humano,

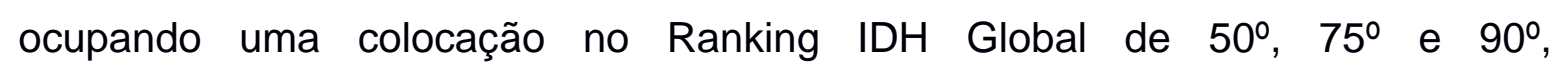
respectivamente, em 2014. Já África do Sul e Índia, ocupam $116^{\circ}$ e $130^{\circ}$, respectivamente, delimitados como países de médio desenvolvimento humano.

Outros dois indicadores que merecem notoriedade são as taxas de inflação e de desemprego, onde infelizmente apresentam resultados insatisfatórios, como é representado na Tabela 2. De acordo com o banco de dados da Trending Economic, é possível notar altas taxas em ambos os índices, principalmente para a África do Sul que está entre os países com as piores porcentagens. A inflação também foi um problema persistente para a Índia, que em 2009 ultrapassou os $14 \%$, conseguindo reduzir apenas a partir de 2012. Especialmente no Brasil e Rússia, a taxa de inflação vem oscilando ao longo dos anos, o que acarreta uma incerteza financeira e consequentemente uma preocupação nos investimentos privados.

Tabela 2 - Taxa média de inflação e de desemprego dos países pertencentes aos BRICS nos anos de 2010 e 2015

\begin{tabular}{|c|c|c|c|c|}
\hline \multirow{2}{*}{ 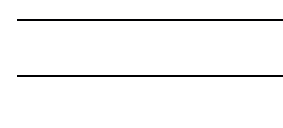 } & \multicolumn{4}{|c|}{ Taxa de Desempreqo (\%) } \\
\hline & 2010 & 2015 & 2010 & 2015 \\
\hline
\end{tabular}




\begin{tabular}{ccccc}
\hline Brasil & 5,04 & 3,46 & 6,75 & 6,60 \\
Rússia & 6,86 & 3,69 & 7,30 & 5,96 \\
Índia & 12,11 & 2,49 & 10,20 & 10,40 \\
China & 3,17 & 1,59 & 4,14 & 4,09 \\
África do Sul & 4,10 & 5,19 & 24,88 & 25,82 \\
\hline
\end{tabular}

Fonte: Elaborada pela autora a partir de dados da Worldwide Inflation Data e Actualitcs.

Ao se comparar estas taxas ao longo de cinco anos, mais especificamente nos anos de 2010 e 2015, é possível notar que a taxa de desemprego se manteve próxima para os países, sem muitas oscilações. A África do Sul permaneceu com seus altos índices, elevando em quase 1\% o número de jovens desempregados, já a Rússia seguiu o caminho inverso e apresentou a melhora mais plausível no grupo, reduzindo em mais de $2 \%$ a desempregabilidade no país.

Resultados mais satisfatórios são apresentados dentre as taxas de inflação que em cinco anos teve uma melhora em torno de $2 \%$ para China, Brasil e Rússia, esta última com o IPC (Índice de Preços ao Consumidor) caindo pela metade. A Índia revelou números ainda mais expressivos, já que em 2010 apresentava a maior taxa entre os países-membros dos BRICS, com mais de 12\% e em 2015 se posicionou entre os menores valores com uma inflação de 2,49\%. Já a África do Sul, foi a única que manifestou uma piora dos preços em seu território, com um aumento de $1 \%$ na taxa inflacionária.

Apesar da precariedade em algumas áreas, tais como saúde, desemprego e educação (com exceção da China), em suma, os países do grupo também possuem similaridades econômicas, como por exemplo, no volume de exportação de recursos minerais e commodities, mão de obra abundante e barata, e o crescimento regulado. De acordo com o BNDES (2011), o comércio intragrupo é baseado nas vantagens comparativas, refletindo nas especializações peculiares de cada país.

Segundo o "The Observatory of Economic Complexity" (OEC), a maior parte das exportações brasileiras são baseadas nos produtos primários, como soja e trigo. No ano de 2015, com um valor exportado de US\$ 195 bilhões e importado US $\$ 170$ bilhões, a balança comercial totalizou um saldo positivo de $\$ 25,3$ bilhões de dólares (Tabela 3). Os principais produtos exportados foram a Soja, o Minério de Ferro, o Petróleo Bruto, o Açúcar Bruto e as Carnes de Aves, já a cesta dos produtos importados consiste nos Petrolíferos Refinados, Petróleo Bruto, Peças de Veículos e Carros. Os principais destinos de exportação do Brasil são a China, os 
Estados Unidos, a Argentina, a Holanda e a Alemanha. Já as origens de importação são a China, os Estados Unidos, a Alemanha, a Argentina e a Coreia do Sul.

No que diz respeito à Rússia, apesar de possuir grande quantidade de recursos naturais disponíveis como ferro e aço, igualmente no Brasil, a Federação Russa se difere da nação brasileira por possuir um território altamente industrializado. Em 2015 a balança comercial da Rússia teve um saldo positivo de US\$132 bilhões - com um valor exportado de US\$316 bilhões e importado de US\$ 184 bilhões. Dentre os principais produtos comercializados internacionalmente estão o Petróleo Bruto, Petrolíferos Refinados, Briquetes de Carvão e Alumínio, com destino de exportação para Holanda, China, Alemanha, Itália e Belarus. E dentre os produtos de importação, destacam-se os Carros, Medicamentos Embalados, Peças de Veículos, Unidades de Disco Digital e Aviões e/ou helicópteros, advindos principalmente da China, Alemanha, Estados Unidos, Belarus e Itália.

A Índia é o menos desenvolvido em comparação ao restante do grupo, contudo, vem sendo alvo de grandes investimentos estrangeiros, além de se destacar na produção têxtil e de tecnologia. Em 2015, sua balança comercial teve um deficit de \$92,6 bilhões de dólares, sendo US\$276 bilhões do valor exportado e US\$ 368 bilhões das importações. Suas exportações estão envoltas de produtos como Petrolíferos Refinados, Diamantes, Medicamentos Embalados, Joias e Arroz, com destino principalmente para os EUA, Emirados Árabes, China e Reino Unido. Dentre os produtos importados estão o Ouro, o Diamante, os Briquetes de Carvão e o Petróleo, originados da China, Suíça, EUA, Arábia Saudita e Emirados Árabes.

Já a China, a fim de recuperar as décadas perdidas de socialismo, vem recebendo maior destaque nos indicadores de desenvolvimento e volume de exportação, principalmente nos bens de consumo e tecnologia. É considerada como a maior economia de exportação do mundo, com um saldo positivo na balança comercial, em 2015, de \$1,1 trilhões de dólares, sendo US $\$ 2,37$ trilhões das exportações e US\$1,27 trilhões das importações. Dentre os produtos exportados estão as Unidades de Disco Digital, os Equipamentos de Transmissão, os Circuitos Integrados e as Peças de Máquinas de Escritório, com destaque para os países de destino, os EUA, Japão, Alemanha e a Coreia do Sul. Já em relação 
aos produtos importados, temos o Petróleo Bruto, os Circuitos Integrados, Ouro, Minério de Ferro e Carros, com origens principais da Coreia do Sul, EUA, Japão e Alemanha. Como menciona Paulo Roberto de Almeida, em seu artigo sobre "O Papel dos BRICS na economia Mundial", de todos, a China é a única economia emergente que de fato, objetiva em converter-se em economia dominante.

Por último, a África do Sul se distingue por ser um dos maiores exportadores de minério da Terra, com destaque para o Ouro, Platina, Manganês, Carros e Diamante. Seus principais países de exportação são a China, os EUA, Índia, Reino Unido e Alemanha, totalizando um valor de \$ 93,7 bilhões de dólares. Dentre o valor de US\$ 80,8 bilhões importado, estão produtos como Petrolíferos Refinados, Carros, Ouro e as Unidades de Disco Digital, com origem de importação da China, Alemanha, EUA, Nigéria e Índia. Neste ano, a balança comercial indiana, teve um saldo positivo de $\$ 12,9$ bilhões de dólares.

Tabela 3 - Balança Comercial dos BRICS, no ano de 2015

\begin{tabular}{lccc}
\hline & $\begin{array}{c}\text { Saldo da Balança } \\
\text { Comercial } \\
\text { (bilhões) }\end{array}$ & $\begin{array}{c}\text { Valor Exportado } \\
\text { (bilhões) }\end{array}$ & $\begin{array}{c}\text { Valor Importado } \\
\text { (bilhões) }\end{array}$ \\
\hline Brasil & US $\$ 25$ & US $\$ 195$ & US $\$ 170$ \\
Rússia & US $\$ 132$ & US $\$ 316$ & US $\$ 184$ \\
Índia & US $\$-92,6$ & US $\$ 276$ & US $\$ 368$ \\
China & US $\$ 1.100$ & US $\$ 2.370$ & US $\$ 1.270$ \\
África do Sul & US $\$ 12,9$ & US $\$ 93,7$ & US $\$ 80,8$ \\
\hline
\end{tabular}

Fonte: Elaborada pela autora a partir de dados da OEC.

Sintetizando, o Brasil, basicamente se evidencia com alimentos, bebidas e insumos industriais. Índia e a China se aprimoram também em insumos industriais para o restante do grupo, gerando concorrência entre elas, contudo, se tratando de valor, a China se destaca pelo fornecimento de bens de capital. A Rússia se direciona para bens de capital e equipamentos de transporte, o que gera uma exceção, já que para o restante do mundo, a maior parte de suas exportações são voltadas para os combustíveis e lubrificantes. Por fim, a África do Sul se sobressai, devido a importância dos BRICS na demanda por seus bens de consumo e de capital (BNDES, 2011).

Ao especificar as relações comerciais bilaterais entre Brasil e os demais integrantes dos BRICS, encontra-se a concentração de produtos provenientes de 
recursos minerais em troca de, basicamente, diversas manufaturas, com algumas poucas exceções. A composição da pauta de exportações brasileiras para a Rússia se define principalmente pela carne bovina, açúcar e tratores. Para Índia se destacam o cobre, o óleo de soja e aeronaves. Dentre os produtos comercializados para a China, têm-se a soja em grãos, minério de ferro e a celulose. E, para a África do Sul, carne de aves, açúcar e transportes ferroviários.

\section{FUNDAMENTAÇÃO TEÓRICA}

\section{Teorias do Comércio Internacional}

Ao abordar o tema de economia internacional, alguns pesquisadores podem ser destacados, como John Stuart Mill, Jean Batista Say, David Ricardo e Adam Smith. Esses dois últimos criaram, respectivamente, as teorias das vantagens comparativas e absolutas (SILVA, 2016).

A teoria da Vantagem Absoluta, de Adam Smith em 1776, parte da ideia de que cada país deve se convergir na produção de mercadorias e produtos que sejam mais vantajosos, levando em consideração os custos, condições de clima, qualificação de mão de obra, localização e proveito de recursos naturais existentes. Assim sendo, cada país deveria produzir e exportar aquilo que possui uma vantagem de custo absoluto e importar dos países aquilo que também oferecesse vantagem de custo absoluto, possibilitando uma vantagem recíproca. Desse modo, existiria certa divisão global de trabalho, onde cada país se especializaria somente na produção de mercadorias com melhores conjunturas econômicas de se realizar, obtendo ganhos com o comércio internacional (REIS, 2008).

Mais tarde, David Ricardo, questionou a relação de comércio fundamentada em um custo absoluto e criou a teoria da Vantagem Comparativa, que assim como Adam Smith, defende a produção com qualidade e menor custo, contudo, acrescenta a necessidade em manter um superavit comercial ou uma balança comercial positiva (RICARDO, 1817).

Basicamente, a teoria da Vantagem Comparativa interpreta que a condição para existir um comércio entre dois países seria apenas que o custo de oportunidade de produzir um bem fosse diferente entre eles. Dessa forma, cada país se especializaria na produção do produto em que possui determinada vantagem, seja na redução de custos para se produzir, na disponibilidade de 
recursos naturais, na infraestrutura, na mão de obra barata ou até vantagens adquiridas para se exportar. Em compensação, importaria aquilo que seu custo de fabricação fosse elevado. Consequentemente, acarretaria maiores oportunidades de comércio com mercadorias em maior qualidade. Ou seja, o que importa não é o custo absoluto de produção, mas a razão e a eficácia de se produzir (SILVA, 2016).

Sem nenhuma explicação satisfatória referente aos motivos das funções de produção divergissem entre os países, dois economistas suecos, Eli Heckscher e Bertil Ohlin, em 1919, aprimoraram a teoria das vantagens comparativas e apresentaram um modelo em que a presença de um comércio entre nações é explicada pela diferença de fatores produtivos existentes, isto é, a depender dos fatores disponíveis, os preços relativos às mercadorias produzidas poderiam variar (FIGUEIREDO; SANTOS, 2005). De acordo com Istake (2003), um país com uma grande oferta de mão de obra qualificada, exportaria seus produtos com um maior valor agregado, já aqueles que possuem mão de obra não qualificada, exportariam produtos menos elaborados e consequentemente mais baratos.

Para explicar a competitividade internacional e como se revelam os padrões de mercado, uma nova teoria de comércio internacional, conhecida como Teoria Estratégica do Comércio, foi desenvolvida com base nas interações de mercados imperfeitamente competitivos que potencializam a importância da diferenciação de produtos, o progresso tecnológico e as economias de escala. Diferentemente dos modelos clássicos de comércio internacional que já não atendem mais o ambiente da economia moderna, justamente por não levar em consideração fatores como as estratégias das empresas e o processo de melhoria e diferenciação dos produtos frente a competição acirrada da globalização (MOREIRA, 2012).

Dentro deste cenário de concorrência e vantagem comparativa, Krugman Obstfeld (2005) pensou no comércio internacional como sendo dividido em duas partes: comércio interindústria e intra-indústria. A primeira, refletindo de maneira fundamental a vantagem comparativa, se sucede da troca de um produto por outro, como manufaturas por alimentos citados pelo próprio autor. Já no segundo caso, tem-se o comércio fundamentado nas economias de escalas, onde ambos os países comercializam os mesmos produtos, gerando a redução do número de produtos produzidos, aumentando a variedade, numa escala maior e com custos mais baixos. 
Basicamente, enquanto no comércio interindústria a vantagem comparativa detém um papel importante e essencial no comércio, o comércio intra-indústria apresenta como as economias de escala conseguem estimular o comércio por si só.

O comércio intra-industria também pode ser positivamente explicado pela participação dos países em um modelo de comércio comum, como um bloco econômico, por exemplo. Isso é explicado, pois quanto menos barreiras comerciais existirem entre as relações bilaterais mais ativamente os Estados participarão deste comércio. Assim, como reforça Hidalgo (1993), o desenvolvimento da integração econômica e a maior liberalização comercial entre seus membros estimulam o crescimento intra-industrial.

\section{Integração Regional}

O conceito de integração é usado em inúmeros contextos. Inicialmente, é usado no campo da sociologia designando o processo pelo qual o indivíduo se coloca na sociedade a fim de socializar, ou seja, basicamente é a integração do indivíduo na coletividade (RHEIN, 2002). Estudiosos em Relações Internacionais expressaram a ideia de que a "integração é um processo baseado menos sobre a formação de uma comunidade do que sobre o estabelecimento de uma organização (regional) ou de uma associação ou de instituições políticas comuns" (DEUTSCH et all, 1957 apud RICHARD, 2014) ou ainda que essencialmente fosse a criação de um Estado Federal. Nesse contexto, Stanley Hoffmann (1990) e Andrew Moravcik (1993) enfatizaram o conceito como sendo a criação de instituições internacionais que tenham o poder de organizar e promover as negociações entre os Estados.

Alguns estudos incitam a integração como sendo conjuntos regionais definidos pelo agrupamento das nações seguindo o curso de suas fronteiras. Entretanto, apenas os conjuntos firmados em tratados são levados em consideração pela maioria dominante das pesquisas realistas. Dessa forma, algumas questões são levantadas por confundir um acordo regional, que poderia ser definidos geograficamente, muito similar a divisão dos continentes, com a integração das nações, que sugere níveis distintos de cooperação. William Thompson (1973) se aprofundando no conceito de região criou uma lista de atribuições para definir uma região, e concluiu que a relação territorial não é uma 
condição necessária. Os Estados que escolhem formar um grupo regional, escolhem seus parceiros a partir de seus interesses e o nível de participação pretendida.

À vista disso, o termo integração regional se manifesta na formação de um conjunto integrado de dois ou mais países, podendo ou não serem ligados geograficamente, entretanto, ligados por um acordo regional, a fim de alcançarem objetivos em comum, como eliminar barreiras de comércio e facilitar a inserção de suas economias no encadeamento da globalização. Esse processo, normalmente, se caracteriza por várias etapas econômicas como a) zona de livre comércio, b) uniões aduaneiras, c) mercados comuns, d) uniões econômica e monetárias e outros que ao se estender para os âmbitos políticos e sociais, se tornam integrações (FERREIRA, 2009).

As Zonas de Livres de Comércio são caracterizadas pela eliminação das antigas tarifas alfandegárias e demais regulamentações restritivas e a criação de novas tarifas preferenciais de exportação e importação para que melhor atendam os produtos originários dos Estados-membros da zona e que de igual forma respeite as pautas em relação aos países não-membros (BALASSA, 1961 apud FERNANDES, 2007).

A União Aduaneira, lograda a Zona de Livre Comércio, é o segundo passo para integração e estabelece uma tarifa exterior comum referentes às importações de produtos provenientes de terceiros países, ou seja, os bens e serviços oriundos de países extra-bloco garantem os mesmos direitos alfandegários independentemente do país onde ingressar, possibilitando a livre circulação destes produtos dentro do bloco (IPEA, 2007).

A terceira etapa consiste na consolidação do Mercado Comum, também conhecido como Mercado Único ou Mercado Interior, composto por cinco liberdades essenciais: a) a livre circulação de bens que supõe uma política comercial comum e o estabelecimento da Tarifa Externa Comum referente a nações não pertencentes ao grupo; b) a livre circulação de trabalhadores garantindo a liberdade de entrada, deslocamento, residência e até de trabalho sob mesmas condições de trabalhadores nacionais; c) livre circulação de pessoas reforçando a facilidade das políticas de imigração, asilo e vistos; d) a livre prestação de serviços e a liberdade de estabelecimento que protegem os empresários individuais, as sociedades e os trabalhadores autônomos; e por fim, 
e) livre circulação de capitais definida pela privação de todas as restrições e discriminações aos movimentos de capitais em razão da nacionalidade (FERREIRA, 2009).

O último estágio do processo integracionista é a União Econômica e Monetária. Uma característica marcante dessa etapa é a criação de um Banco Central Comunitário que em conformidade com os Bancos Nacionais atendam as economias dos países-membros a fim de ter um maior controle sobre o capital circulado, ao passo que ao longo dos anos caminhe para a obtenção de uma moeda única (FERREIRA, 2009).

\section{MATERIAL E MÉTODO}

Índice de Intensidade de Comércio (IIC)

Desenvolvido por Anderson e Norheim (1993), o IIC observa o progresso dos interesses no comércio europeu, além de demonstrar a tendência dos países a realizarem trocas ou comercializarem entre eles baseados em dados de exportação e importação mundial. Para analisar apenas a celulose, setor foco do estudo, usa-se uma versão adaptada, onde o IIC do país i para o país j considera o setor k na (equação 1):

$I I C_{i j}^{k}=\frac{\left(\frac{x_{i j}^{k}}{x_{i}^{k}}\right)}{\frac{M_{j}^{k}}{M_{w}^{k}}}$

Em que $X_{i j}^{k}$ representam as exportações brasileiras do setor de e celulose para o BRICS; $X_{i}$, as exportações totais do Brasil deste mesmo setor; $M_{J}$, as importações totais do segmento de celulose do BRICS; e $M_{w}$, as importações totais mundiais do mesmo.

Desse modo, um indicador maior do que 1 (um) mostra que os fluxos bilaterais de comércio são maiores do que o esperado, dado o peso do parceiro comercial no comércio mundial, portanto é um mercado importante para o Brasil. No entanto, se o IIC for menor ou igual a 1 (um) indica que peso das exportações brasileiras para o BRICS é igual ao peso do BRICS no total das importações mundiais, ou seja, exportar ou não para esses países se torna indiferente. 
Índice de Orientação Regional de Comércio

Para estimar o peso de um produto ou seção nas exportações totais intrabloco em comparação ao peso de suas exportações totais para o restante do mundo, isto é, a efetividade dos BRICS em exportar para outros países, usa-se o Índice de Orientação Regional (IOR) (equação 2):

$\operatorname{IOR}_{I}=\frac{\left(\frac{x_{x_{j}}}{x_{j i j}}\right)}{\left(\frac{x_{o j}}{X}\right)}$

Onde, $X_{r j}$ representa o valor das exportações do Brasil da celulose no comércio intra-bloco ou intra-zona; $x_{t j}$, o valor das exportações totais brasileiras também no comércio intra-bloco; $x_{o j}$, o valor das exportações do Brasil da celulose no comércio extra-bloco ou extra-zona; e $X$ para o valor das exportações totais brasileiras no comércio extra-bloco.

Em que, valores maiores que 1 (um) apontam uma orientação vantajosa ao comércio regional, ao passo que, valores menores que 1 (um) indicam uma orientação conveniente às relações do Brasil com terceiros mercados. Ou seja, valores elevados mostram uma intensidade maior de comércio entre os paísesmembros do bloco e, como resultado, haverá reorientação das exportações brasileiras em direção aos demais parceiros comerciais.

Índice de Grubel e Lloyd (GL) e Índice de Menon e Dixon (CT)

Segundo Grubel e Lloyd (1975), o comércio intra-indústria (CII) é deliberado como o valor das exportações compensado exatamente pelas importações da mesma indústria (equação 3).

$G L_{i}=\frac{\left(X_{i}+M_{i}\right)-\left|X_{i}-M_{i}\right|}{\left(X_{i}+M_{i}\right)}$

Em que, $X_{i}$ e $M_{i}$ indicam, respectivamente, o valor das exportações e importações da indústria $\mathrm{i} ;\left(X_{i}+M_{i}\right)$ representa o comércio total da indústria i; $\left|X_{i}-M_{i}\right|$, o comércio inter-indústria e $\left(X_{i}+M_{i}\right)-\left|X_{i}-M_{i}\right|$, o comércio intraindústria como um todo.

O índice é zero quando o comércio for explicado pelo comércio interindústria (CEI), contudo, quando o comércio for intra-indústria, o índice é igual a 1 
(um) (quando o valor das exportações é igual ao valor das importações). Vale destacar que quanto mais próximo do 1 maior será o nível de agregação setorial.

O Índice GL seria uma medida estática, que detêm apenas o índice intraindústria em um determinado período de tempo, conforme Hamilton e Kniest (1991). Contudo, o primordial não seria o quanto o comércio intra-indústria vem crescendo, mas sim o quanto esse crescimento contribuiria para o comércio no total. Menon e Dixon (1995), pensando a respeito da mensuração do Cll e da colaboração para uma mudança no comércio total, simplificam este mesmo comércio total da indústria k entre os países i e j, na soma do comércio intraindústria com o de inter-indústria. Assim, o valor de crescimento do comércio total é definido por (equações a 6 ):

$C T_{i j k}=\operatorname{Ccei}_{i j k}+\operatorname{Ccii}_{i j k}$

Em que:

$$
\begin{aligned}
& \text { Ccei }=(1-G L) \times c e i_{i j k} \\
& \text { Ccii }_{i j k}=G L \times c i i_{i j k}
\end{aligned}
$$

Sendo que, $c e i_{i j k} \mathrm{e} c i i_{i j k}$ indicam, respectivamente, o comércio interindústria e o comércio intra-indústria. As equações (5) e (6) medem, respectivamente as contribuições do crescimento do comércio inter-indústria e intra-indústria para o crescimento total do comércio.

\section{Fontes de Dados}

Para o cálculo dos índices, foram utilizados dados da Food and Agriculture Organization of the United States (FAO) e os valores totais das exportações do Brasil para os BRICS, do Ministério de Desenvolvimento, Indústria e Comércio Comex Sat

Ressalta-se que a definição do intervalo de análise, foi posto em virtude da abertura da economia a partir da década de 90, bem como da disponibilidade de dados, estabilização da economia com o plano real e da formação dos BRICS. Assim, foi possível estudar e comparar o cenário comercial brasileiro do segmento de celulose com o período anterior ao surgimento do BRICS (1997 a 2008) e posterior à formação do BRICS (2009 a 2016).

\section{RESULTADOS E DISCUSSÃO}


Índice de Intensidade de Comércio

Nota-se durante todo o período, com exceção do ano de 2005, o IIC entre Brasil e BRICS foi inferior ou igual a 1 (um), o que indicou o BRICS como um mercado indiferente para o Brasil (Tabela 4).

Tabela 4 - Evolução do índice de Intensidade de Comércio (IIC) do segmento de celulose entre Brasil e os países dos BRICS, no período de 1997 a 2016

\begin{tabular}{cccccc}
\hline Ano & $\begin{array}{c}\text { Brasil- } \\
\text { BRICS }\end{array}$ & $\begin{array}{c}\text { Brasil- } \\
\text { Rússia }\end{array}$ & Brasil-Índia & Brasil-China & $\begin{array}{c}\text { Brasil-África } \\
\text { do Sul }\end{array}$ \\
\hline 1997 & 0,51 & 0,00 & 0,01 & 0,64 & 0,00 \\
1998 & 0,38 & 0,00 & 0,01 & 0,46 & 0,00 \\
1999 & 0,36 & 0,00 & 0,13 & 0,42 & 0,00 \\
2000 & 0,28 & 0,03 & 0,27 & 0,31 & 0,00 \\
2001 & 0,65 & 0,00 & 0,23 & 0,72 & 0,00 \\
2002 & 0,50 & 0,00 & 0,01 & 0,55 & 1,88 \\
2003 & 0,24 & 0,00 & 0,11 & 0,19 & 7,82 \\
2004 & 0,82 & 0,02 & 0,06 & 0,86 & 5,98 \\
2005 & 1,37 & 0,09 & 2,25 & 1,38 & 1,76 \\
2006 & 1,00 & 0,13 & 0,04 & 1,12 & 0,02 \\
2007 & 0,64 & 0,22 & 0,05 & 0,70 & 0,00 \\
2008 & 0,76 & 1,32 & 0,01 & 0,83 & 0,81 \\
2009 & 1,08 & 1,11 & 0,05 & 1,17 & 0,27 \\
2010 & 0,84 & 1,27 & 0,02 & 0,91 & 0,29 \\
2011 & 0,80 & 0,79 & 0,22 & 0,86 & 0,26 \\
2012 & 0,79 & 0,84 & 0,02 & 0,87 & 0,03 \\
2013 & 0,92 & 0,45 & 0,06 & 1,01 & 0,54 \\
2014 & 0,95 & 0,52 & 0,02 & 1,05 & 0,34 \\
2015 & 0,91 & 0,96 & 0,03 & 1,00 & 0,25 \\
2016 & 0,93 & 0,42 & 0,09 & 1,14 & 2,12 \\
\hline Média (1997 a 2016) & 0,74 & 0,41 & 0,18 & 0,81 & 1,12 \\
Media (1997 a 2008) & 0,63 & 0,15 & 0,27 & 0,68 & 1,52 \\
\hline Media (2009 a 2016) & 0,90 & 0,80 & 0,06 & 1,00 & 0,51 \\
\hline
\end{tabular}

Fonte: Elaborada pela autora a partir de dados da FAO (2018).

Contudo, percebe-se um aumento na intensidade de comércio entre os países-membros dos BRICS, após sua formação.

O IIC médio entre 1997 e 2008, período que antecede a formação do grupo econômico, foi de 0,63 enquanto de 2009 em diante está média subiu para 0,90, 
indicando tendência crescente e até com níveis mais estáveis, o que supõe um reflexo da redução de tarifas e maior liberalização comercial (Tabela 4).

Analisando o comércio do Brasil com os demais países de forma isolada, verifica-se crescimento do IIC médio entre Brasil e Rússia e Brasil e China, de $427 \%$ e $47 \%$, respectivamente (Tabela 4 ).

No que se refere a China, o IIC setorial Brasil-China ultrapassou a unidade em alguns anos, alcançando uma média pós-BRICS de 0,81, sendo que entre 1997 a 2008 esse número se manteve em 0,68, ou seja, depois da formação dos BRICS, o IIC teve um aumento de 47\% até o ano de 2016 (Tabela 4).

O país que mais se destacou ao longo em relação ao IIC foi a Rússia. O IIC médio entre os anos de 1997 a 2008 era de apenas 0,15 e após a formação dos BRICS, esse valor teve um acréscimo de 427\%, até 2016 (Tabela 4). O comércio entre as duas nações se estreitou não apenas no segmento da celulose, mas também, no setor de carne, adubos e fertilizantes e até no que diz respeito à cooperação espacial. De acordo com Presidência da República (2018), esse número tende a aumentar já que em 2017 o investimento nessa relação econômica foi 329\% maior que o ano de 2016. Depois de uma recessão provocada pela queda no preço do petróleo e pelas sanções ocidentais causadas pela crise em 2009, a Rússia começa a se reerguer em 2015, voltando a um crescimento real no PIB de 1,5\% ao ano, o que pode explicar o crescimento da economia e a intensificação bilateral do comércio com o Brasil no segmento de celulose.

Diferentemente dos outros membros, a Índia e a África do Sul, foram os países que apresentaram queda no IIC médio após a formação dos BRICS, 76\% e $66 \%$, respectivamente, de redução no IIC (Tabela 4).

No caso específico da Índia, a queda no IIC médio pode ser explicada pelo aumento da desigualdade social do país nos últimos anos. Os níveis de pobreza, desnutrição, analfabetismo, e inflação permanecem muito altos, e a dívida externa do país cresce no mesmo passo do crescimento populacional.

Já a África do Sul, em 2003 obteve o maior IIC entre os membros (8,0). O IIC médio no pré-BRICS foi de 1,52 e a partir do ano de 2009, esse valor reduziu para 0,51, o que corresponde a uma queda de 66\% (Tabela 4).

Em síntese, de um modo geral, consta-se que após a formação dos BRICS intensificou-se o fluxo comercial da celulose com os países membros, mesmo os 
valores do IIC se apresentarem inferiores à unidade na maioria dos anos analisados e na média.

Índice de Orientação Regional

Os IORs calculados para o segmento da celulose mostraram-se, na maior parte do período, valores maiores que 1, que supõe relações comerciais mais voltadas para o intra-bloco, do que com o restante do mundo. As únicas exceções, seguindo o mesmo padrão do IIC, são dos anos de 2000 e 2003, antes da formação do grupo (Tabela 5).

Tabela 5 - Evolução do índice de Orientação Regional (IOR) das exportações brasileiras para o segmento de celulose, no período de 1997 a 2016

\begin{tabular}{|c|c|c|c|c|c|}
\hline Ano & $\begin{array}{l}\text { Brasil- } \\
\text { BRICS }\end{array}$ & $\begin{array}{l}\text { Brasil- } \\
\text { Rússia }\end{array}$ & Brasil-Índia & Brasil-China & $\begin{array}{c}\text { Brasil-África } \\
\text { do Sul }\end{array}$ \\
\hline 1997 & 1,08 & 0,00 & 0,03 & 2,41 & 0,00 \\
\hline 1998 & 1,09 & 0,00 & 0,03 & 2,35 & 0,00 \\
\hline 1999 & 1,15 & 0,00 & 0,13 & 3,41 & 0,00 \\
\hline 2000 & 0,99 & 0,01 & 0,33 & 1,81 & 0,00 \\
\hline 2001 & 1,72 & 0,00 & 0,30 & 3,39 & 0,00 \\
\hline 2002 & 1,07 & 0,00 & 0,01 & 2,05 & 0,42 \\
\hline 2003 & 0,65 & 0,00 & 0,13 & 0,43 & 1,28 \\
\hline 2004 & 1,77 & 0,00 & 0,12 & 3,08 & 0,91 \\
\hline 2005 & 2,85 & 0,00 & 2,72 & 4,23 & 0,24 \\
\hline 2006 & 1,78 & 0,01 & 0,07 & 3,15 & 0,00 \\
\hline 2007 & 1,12 & 0,02 & 0,08 & 1,86 & 0,00 \\
\hline 2008 & 2,32 & 0,08 & 0,02 & 3,44 & 0,16 \\
\hline 2009 & 2,20 & 0,07 & 0,03 & 3,14 & 0,05 \\
\hline 2010 & 1,29 & 0,09 & 0,01 & 1,73 & 0,06 \\
\hline 2011 & 1,39 & 0,10 & 0,30 & 1,57 & 0,06 \\
\hline 2012 & 1,35 & 0,18 & 0,02 & 1,77 & 0,01 \\
\hline 2013 & 1,58 & 0,11 & 0,09 & 1,80 & 0,15 \\
\hline 2014 & 1,74 & 0,09 & 0,02 & 2,25 & 0,16 \\
\hline 2015 & 1,76 & 0,21 & 0,04 & 2,21 & 0,08 \\
\hline 2016 & 1,83 & 0,10 & 0,14 & 1,68 & 0,76 \\
\hline Média (1997 a 2016) & 1,54 & 0,05 & 0,23 & 2,39 & 0,22 \\
\hline Média (1997 a 2008) & 1,47 & 0,01 & 0,33 & 2,63 & 0,25 \\
\hline Média (2009 a 2016) & 1,64 & 0,12 & 0,08 & 2,02 & 0,17 \\
\hline
\end{tabular}

Fonte: Elaborada pela autora a partir de dados da FAO (2018). 
Apesar dos maiores valores do IOR terem se apresentado antes do ano de 2009, mais precisamente em 2005 e 2008, é possível notar um aumento do IOR médio ao se comparar os anos que antecedem e sucedem aos BRICS. Entre os anos de 1997 a 2008, o IOR médio apresentou uma média de 1,47 enquanto a partir de 2009, esse valor aumentou para 1,64, isto é, um crescimento de $12 \%$, sugerindo uma orientação vantajosa ao comércio regional, bem como intensidade maior de comércio entre os países-membros do bloco (Tabela 5).

Entretanto, a análise do Brasil com cada país membro indica que apenas o IOR do Brasil com a Rússia apresentou crescimento elevado após a formação dos BRICS da ordem de 1.087,5\%. Com os demais países houve queda de $76 \%, 23 \%$ e 33\%, considerando a Índia, China e África do Sul, respectivamente. No caso da China, houve redução do IOR após a formação dos BRICS, mas mesmo assim esse índice foi elevado (2,02) (Tabela 5).

Observa-se melhor desempenho do IOR para o comércio do Brasil e Rússia e Brasil e China, o que pode ser devido ao crescimento econômico desses países durante o período considerado. Mais precisamente, o consumo de celulose está diretamente relacionado com o consumo de papel, que por sua vez está vinculado ao crescimento da população, à renda e à escolaridade. Isto é, quanto maior a população, a renda e o nível de escolaridade, maior será o consumo de livros, cadernos, papéis de imprimir e escrever, e papéis para fins sanitários. Já na indústria, quanto maior a produção, maior será o fluxo de mercadorias e, portanto, o consumo de embalagens (FAE BUSINESS, 2001).

Índice de Grubel e Lloyd

$\mathrm{Na}$ Tabela 3, apresenta-se a evolução do fluxo de comércio interindústria (CCEI) e intra-indústria (CCII) do segmento de celulose, no período de 1997 a 2015, entre o Brasil e BRICS

Tabela 6 - Evolução do fluxo de comércio interindústria (CCEI) e intra-indústria (CCII) do segmento de celulose, no período de 1997 a 2015, entre o Brasil e BRICS

\begin{tabular}{cccccc}
\hline ANO & $\begin{array}{c}\text { Índice } \\
\text { GL } \\
\text { Brasil- } \\
\text { BRICS }\end{array}$ & $\begin{array}{c}\text { Índice } \\
\text { GL } \\
\text { Brasil- } \\
\text { Rússia }\end{array}$ & $\begin{array}{c}\text { Índice GL } \\
\text { Brasil- } \\
\text { Índia }\end{array}$ & $\begin{array}{c}\text { Índice GL } \\
\text { Brasil-China }\end{array}$ & $\begin{array}{c}\text { Índice GL } \\
\text { Brasil-África } \\
\text { do Sul }\end{array}$ \\
\hline 1997 & 0,00 & 0,00 & 0,00 & 0,00 & 0,00 \\
1998 & 0,00 & 0,00 & 0,00 & 0,00 & 0,00 \\
1999 & 0,00 & 0,00 & 0,00 & 0,00 & 0,00 \\
2000 & 0,00 & 0,00 & 0,00 & 0,00 & 0,00 \\
2001 & 0,00 & 0,00 & 0,00 & 0,01 & 0,00
\end{tabular}




\begin{tabular}{cccccc}
2002 & 0,00 & 0,00 & 0,00 & 0,00 & 0,00 \\
2003 & 0,00 & 0,03 & 0,00 & 0,00 & 0,00 \\
2004 & 0,00 & 0,06 & 0,00 & 0,00 & 0,00 \\
2005 & 0,00 & 0,94 & 0,00 & 0,00 & 0,04 \\
2006 & 0,00 & 0,53 & 0,00 & 0,00 & 0,50 \\
2007 & 0,00 & 0,33 & 0,00 & 0,00 & 0,00 \\
2008 & 0,00 & 0,11 & 0,00 & 0,00 & 0,06 \\
2009 & 0,00 & 0,28 & 0,00 & 0,00 & 0,43 \\
2010 & 0,00 & 0,25 & 0,00 & 0,00 & 0,15 \\
2011 & 0,01 & 0,37 & 0,00 & 0,00 & 0,44 \\
2012 & 0,00 & 0,33 & 0,09 & 0,00 & 0,10 \\
2013 & 0,00 & 0,54 & 0,00 & 0,00 & 0,00 \\
2014 & 0,00 & 0,66 & 0,00 & 0,00 & 0,01 \\
2015 & 0,00 & 0,47 & 0,00 & 0,00 & 0,00 \\
2016 & 0,00 & 0,62 & 0,00 & 0,00 & 0,00 \\
\hline media (1997 a 2016) & 0,00 & 0,28 & 0,00 & 0,00 & 0,09 \\
media (1997 a 2008) & 0,00 & 0,17 & 0,00 & 0,00 & 0,05 \\
media (2009 a 2016) & 0,00 & 0,44 & 0,01 & 0,00 & 0,14 \\
\hline
\end{tabular}

Fonte: Elaborada pela autora a partir de dados da FAO (2018).

$\mathrm{Na}$ Tabela 6 verificou-se que os fluxos de comércio de celulose entre Brasil e China e Brasil e Rússia seguiram um padrão crescente do comércio interindústria. A Rússia, em específico, mostrou um CCll maior que 0,5 nos anos de 2005, 2013, 2014 e 2016 e com isso um índice GL acima de 0,5 indicando dotação de fatores distinta, ou seja, predominância do comércio intra-indústria. Porém, na média de todo o período o índice GL da Rússia apresentou-se menor que zero, assim como nos períodos anterior e posterior à formação dos BRICS sugerindo um comércio interindústria do Brasil com a Rússia no segmento de celulose (Tabela 6).

Já, o comércio com a China é inteiramente classificado como interindústria, tendo o GL alcançando um máximo de 0,1 em 2001 (Tabela 6).

O comércio de celulose com a Índia, assim como a China, revelou a inexistência das economias de escala e diferenciação de produtos, ou seja, o comércio é inteiramente interindústria já que o GL se manteve em 0 durante quase todo período analisado, com exceção do ano de 2015 que esse número chegou a quase uma unidade revelando dotação idêntica de fatores e um comercio intraindústria. Por outro lado, considerando o índice GL médio nos períodos estudados, 
este foi próximo de zero indicando um comércio interindustrial da celulose entre esses dois Brasil e Índia (Tabela 6).

Por fim, o fluxo de comércio de celulose entre Brasil e África do Sul também apresentou-se interindustrial.

Sendo assim, observou-se a predominância dos valores iguais à zero ou próximos de zero para o índice $\mathrm{GL}$, ou seja, a predominância do comércio interindústria no fluxo comercial da celulose do Brasil com os BRICS e do Brasil com cada país membro dessa aliança comercial. Mesmo como a formação dos BRICS não houve alteração nesse índice. Isso pode ser explicado pelo fato de o Brasil ser um dos maiores produtores e exportadores mundiais de celulose e também pelo fato da celulose ser uma commodity e não um produto diferenciado, não sendo necessário importar dentro da mesma indústria, o que caracterizaria um comércio inter-indústrial.

Em outras palavras, o CCII se baseia nas trocas de bens semelhantes entre os países, necessitando diferenciação e industrialização do produto em questão, que, por sua vez, tende a aumentar quanto mais diferenciado for este. Considerando que na pauta comercial da produção de celulose predomina a comercialização da commodity pasta química de madeira, o baixo grau de diferenciação atribui baixo comércio intra-indústria no segmento.

\section{4 Índice de Menon e Dixon}

Conforme verificado, os resultados indicados na Tabela 7, mostram a predominância do comércio inter-indústria para o crescimento do comércio total de celulose entre Brasil-BRICS e entre Brasil e cada país parceiros do grupo na grande maioria dos anos analisados.

No caso do fluxo comercial da celulose com o Brasil e o BRICS, o CCEI médio de 1997 a 2016 foi de 32,05\%. Antes dos BRICS, apresentou média de $42,12 \%$ e depois dos BRICS, 16,92\%, indicando a predominância do comércio interindustrial sobre o intra-industria (Tabela 7).

Analisado o fluxo comercial da celulose do Brasil com cada país do BRICS, também se verificou a predominância do comércio interindustrial sobre o intraindústria durante cada ano e nos períodos analisados, exceto para o Brasil e Rússia e Brasil e África do Sul, em que o CCII apresentou-se maior após a formação dos BRICS (Tabela 7). Porém, esse resultado foi devido ao maior valor observado no ano de 2005 para a Rússia e em 2011 para a África do Sul. Porém, 
como já foi dita anteriormente, na grande maioria dos anos o CCEI foi maior que o CCII. Pode-se dizer, então, que ao longo do período analisado, houve uma maior contribuição por parte do CCEI, o que mostra a predominância do comércio interindústria em relação à contribuição do comércio intra-indústria (Tabela 7).

Tabela 7 - Contribuição percentual do comércio interindústria (CCEI) e intra-indústria (CCII) para o crescimento do fluxo de comércio da celulose para os BRICS e para o Brasil e os países constituintes dos BRICS, nos anos de 1997 a 2016

\begin{tabular}{|c|c|c|c|c|c|c|c|c|c|c|c|c|c|c|c|}
\hline \multirow{2}{*}{ Ano } & \multicolumn{3}{|c|}{ Brasil-BRICS } & \multicolumn{3}{|c|}{ Brasil-Rússia } & \multicolumn{3}{|c|}{ Brasil-Índia } & \multicolumn{3}{|c|}{ Brasil-China } & \multicolumn{3}{|c|}{ Brasil-África do Sul } \\
\hline & CCEI & CCII & CTI & CCEI & CCII & CTI & CCEI & CCII & CTI & CCEI & CCII & CTI & CCEI & CCII & CTI \\
\hline 1997 & 0,00 & 0,00 & 0,00 & 0,00 & 0,00 & 0,00 & 0,00 & 0,00 & 0,00 & 0,00 & 0,00 & 0,00 & 0,00 & 0,00 & 0,00 \\
\hline 1998 & $-13,48$ & 0,00 & $-13,48$ & 0,00 & 0,00 & 0,00 & $-11,76$ & 0,00 & $-11,76$ & $-13,48$ & 0,00 & $-13,48$ & 0,00 & 0,00 & 0,00 \\
\hline 1999 & 36,82 & 0,00 & 36,82 & 0,00 & 0,00 & 0,00 & $1.354,67$ & 0,00 & $1.354,67$ & 35,40 & 0,00 & 35,40 & 0,00 & 0,00 & 0,00 \\
\hline 2000 & 0,08 & 0,00 & 0,08 & 0,00 & 0,00 & 0,00 & 89,92 & 0,00 & 89,92 & $-2,32$ & 0,00 & $-2,32$ & 0,00 & 0,00 & 0,00 \\
\hline 2001 & 121,91 & 4,84 & 126,75 & 100,00 & 0,00 & 100,00 & $-12,21$ & 0,00 & $-12,21$ & 126,96 & 0,00 & 126,96 & $-100,00$ & 0,00 & $-100,00$ \\
\hline 2002 & $-24,03$ & $\overline{-}, 17$ & $-24,20$ & 0,00 & 0,00 & 0,00 & $-92,96$ & 0,00 & $-92,96$ & $-26,02$ & 0,07 & $-26,09$ & 0,00 & 0,00 & 0,00 \\
\hline 2003 & $-22,15$ & 0,21 & $-21,94$ & 13,53 & 0,54 & 14,07 & $1.255,47$ & 0,00 & $1.255,47$ & $-44,25$ & 0,04 & $-44,28$ & 477,03 & 0,00 & 477,03 \\
\hline 2004 & 269,88 & 1,67 & 271,54 & 528,22 & 35,56 & 563,79 & $-22,59$ & 0,00 & $-22,59$ & 406,31 & 0,00 & 406,31 & $-24,61$ & $-0,08$ & $-24,70$ \\
\hline 2005 & 97,40 & $\overline{-}, 06$ & 97,34 & $-5,41$ & 78,28 & $-83,69$ & $3.794,94$ & 0,00 & $3.794,94$ & 88,68 & 0,00 & 88,68 & $-63,61$ & 79,04 & 15,43 \\
\hline 2006 & $-5,85$ & 0,00 & $-5,85$ & 946,28 & 8,79 & $\begin{array}{c}- \\
937,49\end{array}$ & $-97,78$ & 0,00 & $-97,78$ & 4,67 & 0,00 & 4,67 & $-51,68$ & $-5,96$ & $-57,64$ \\
\hline 2007 & $-18,89$ & 0,15 & $-18,74$ & 192,40 & 25,22 & 217,62 & 25,02 & 0,00 & 25,02 & $-19,01$ & 0,00 & $-19,01$ & 138,55 & 0,00 & 138,55 \\
\hline 2008 & 63,83 & 0,05 & 63,88 & 492,96 & 6,62 & 499,58 & $-71,11$ & 0,00 & $-71,11$ & 61,53 & 0,00 & 61,53 & $\begin{array}{c}- \\
2661,65\end{array}$ & $-0,73$ & $\begin{array}{c}- \\
2662,38\end{array}$ \\
\hline 2009 & 57,63 & 0,15 & 57,78 & $-33,76$ & 18,80 & $-14,95$ & 516,90 & 0,00 & 516,90 & 59,61 & 0,00 & 59,61 & $-46,81$ & 46,67 & $-0,13$ \\
\hline 2010 & 2,45 & 0,11 & 2,56 & 81,54 & 22,10 & 103,64 & $-53,11$ & 0,00 & $-53,11$ & 2,16 & 0,00 & 2,16 & 66,53 & $-8,82$ & 57,71 \\
\hline 2011 & 16,79 & 6,08 & 22,87 & $-12,60$ & 15,08 & 2,48 & $1.430,78$ & 0,00 & $1.430,78$ & 16,34 & 0,07 & 16,41 & $-211,25$ & 1816,62 & $1.605,37$ \\
\hline 2012 & $-5,56$ & $\overline{-}$ & $-5,88$ & 28,27 & 5,45 & 33,71 & $-80,90$ & 0,00 & $-80,90$ & $-4,77$ & 0,00 & $-4,77$ & $-36,12$ & $-5,98$ & $-42,10$ \\
\hline 2013 & 28,51 & $\begin{array}{c}- \\
0,17\end{array}$ & 28,35 & $-22,11$ & 12,61 & $-9,51$ & 208,91 & 0,00 & 208,91 & 28,10 & 0,00 & 28,09 & $-310,52$ & 0,00 & $-310,52$ \\
\hline 2014 & 9,17 & 0,29 & 9,46 & $-1,31$ & 39,03 & 37,72 & $-54,90$ & 0,00 & $-54,90$ & 9,60 & 0,00 & 9,60 & $-21,03$ & 0,00 & $-21,03$ \\
\hline 2015 & 7,87 & 0,06 & 7,93 & 76,35 & 5,63 & 81,99 & 62,89 & 0,00 & 62,89 & 7,58 & 0,00 & 7,58 & $-28,49$ & $-0,58$ & $-29,07$ \\
\hline 2016 & 18,53 & $\overline{-}$ & 18,43 & $-24,04$ & $\begin{array}{c}- \\
21,21\end{array}$ & $-45,25$ & 208,65 & 0,00 & 208,65 & 17,11 & 0,00 & 17,11 & 855,37 & $-0,02$ & 855,35 \\
\hline $\begin{array}{c}\text { Media } \\
(1997 \\
a \\
2016)\end{array}$ & 32,05 & 0,64 & 32,69 & 13,39 & 4,80 & 18,19 & 422,54 & 0,00 & 422,54 & 37,71 & 0,00 & 37,71 & $-100,91$ & 96,01 & $-4,91$ \\
\hline $\begin{array}{c}\text { Media } \\
(1997 \\
\text { a } \\
2008)\end{array}$ & 42,13 & 0,56 & 42,68 & 14,62 & $-0,13$ & 14,49 & 517,63 & 0,00 & 517,63 & 51,54 & $\overline{0}, 01$ & 51,53 & $-190,50$ & 6,02 & $-184,48$ \\
\hline $\begin{array}{c}\text { Media } \\
(2009 \\
\text { a } \\
2016)\end{array}$ & 16,92 & 0,76 & 17,69 & 11,54 & 12,19 & 23,73 & 279,90 & 0,00 & 279,90 & 16,97 & 0,01 & 16,97 & 33,46 & 230,99 & 264,45 \\
\hline
\end{tabular}

Fonte: Elaborada pela autora a partir de dados da FAO (2018). 


\section{Considerações finais}

A presente pesquisa possibilitou concluir durante o período analisado que 0 BRICS se caracterizou como um mercado importante para a celulose brasileira, principalmente por causa do comércio com a China e a Rússia. Após a formação dos BRICS o fluxo comercial da celulose brasileira aumentou entre os países membros, principalmente para a China e Rússia.

Com relação à intensidade do comércio, constatou-se que o padrão de comércio verificado no segmento de celulose, entre Brasil e BRICS foi menor que a unidade, assim como do Brasil com cada país membro. Contudo, houve um aumento na intensidade de comércio entre os países-membros dos BRICS após sua formação.

Os IORs calculados para o segmento da celulose indicaram relações comerciais mais voltadas para o intra-bloco, do que com o restante do mundo, sendo que o comércio de celulose do Brasil, principalmente, com a China e a Rússia impactaram esse resultado. E houve um aumento do IOR médio após a formação do BRICS.

Verificou-se, ainda, que o comércio da celulose brasileira com os BRICS foi interindustrial no período analisado.

Sugere-se trabalhos futuros atualizando esta análise do Brasil com 0 BRICS, bem como com outros países grandes consumidores da celulose brasileira como os países da Europa e Estados Unidos.

\section{REFERÊNCIAS}

BANCO NACIONAL DE DESENVOLVIMENTO ECONÔMICO E SOCIAL- BNDES. O Comércio entre os BRICS e suas Oportunidades de Crescimento. (2011). Disponível em <http://www20.iadb.org/intal/catalogo/PE/2011/09015.pdf>. Acesso em 28 ago. 2017.

BAUMANN R. et al. BRICS: Estudos e Documentos. Brasília: FUNAG, 2015. p 22.

CALDAS, R. Q. S. Oferta de Exportação de Papel no Brasil e Contribuição do Segmento para o Desenvolvimento Regional. Dissertação (Mestrado em Economia Regional e Políticas Públicas). 93 f., Universidade Estadual de Santa Cruz, Ilhéus - BA, 2015.

CENTRAL INTELLIGENCE AGENCY - CIA. The World Factbook. Disponível em: < https://www.cia.gov/library/publications/the-world-factbook/rankorder/2147rank.html>. Acessado em: 25 ago. 2017.

CORREA, P. G., LOES, A. Impactos Setoriais do MERCOSUL sobre a Indústria 
Brasileira: Uma Análise com Base no Padrão de Comércio. Anais do Congresso de Economia da ANPEC, Florianópolis - SC, 1994, p. 313-332.

ANDERSON, K.; NORHEIM, H. From Imperial to Regional Trade Preferences: Its Effects on Europe's Intra and Extra Regional Trade, Weltwirthschaftliches Archiv, vol 129, no. 1 (1993), p. 78-101.

FAE BUSINESS. O mercado de papel e celulose. Revista FAE BUSINESS, n.1, nov. 2001, p. 44-45.

FERNANDES, J. A. A Integração Econômica como Estratégia de Desenvolvimento do Continente Africano: Proposta de Fusão entre a Comunidade Econômica dos Estados da África Ocidental (CEDEAO) e a União Econômica e Monetária da África Ocidental (UEMOA). Florianópolis - SC, 2007, p. 35.

FERREIRA, T. J. M. C. As Etapas do Processo de Integração Regional. 2009. Disponível em <https://jus.com.br/artigos/12833/as-etapas-do-processo-de-integracaoregional/1>. Acesso em 22 mar. 2018.

FIGUEIREDO, A. M.; SANTOS, M. L. Evolução das Vantagens Comparativas do Brasil no Comércio Mundial de Soja. Revista de Política Agrícola. Ano XIV - № 1 - Jan./Fev./Mar. 2005.

FOOD AND AGRICULTURE ORGANIZATION OF THE UNITED STATES - FAO. (2017).

Faostat. Acesso em 12/10/2017. Disponível em: <http://www.fao.org/home/en/>.

GUIMARÃES CM. O Mercosul e o Desempenho do Comércio Intra-Indústria do Setor Brasileiro de Papel e Celulose. Dissertação (Mestrado em Economia Aplicada), 100f., Universidade Federal de Viçosa, Viçosa - MG, 2007.

HAMILTON C, KNIEST P. Trade Liberalisation, Structural Adjustment and Intra Industry Trade: A Note. Weltwirtschaftliches Archiv, vol. 12, 1991. p. 356- 367.

HIDALGO, A. B. Intercâmbio comercial brasileiro intra-indústria: uma análise entre indústrias e entre países. Revista Brasileira de Economia, v.1, n.2, p.243-264, abr./jun. 1993.

HOFFMANN SA. New World and its Troubles. Foreign Affairs, vol. 69, n 4, 1990, p.115122.

INDÚSTRIA BRASILEIRA DE ÁRVORES - IBÁ. Celulose. Disponível em:

$<$ http://iba.org/pt/produtos/celulose >. Acesso em: 12/10/2017.

INSTITUTO DE PESQUISA ECONÔMICA APLICADA - IPEA. Conheça o BRICS. 2007. Disponível em: <http://www.ipea.gov.br/forumbrics/pt-BR/conheca-os-brics.html>. Acesso em: 12/10/2017.

ISTAKE, M. Comércio Externo e Interno do Brasil e das suas Macrorregiões: um teste do teorema de Heckscher-Ohlin. Tese (Doutorado em Economia Aplicada). 145f., Escola Superior de Agricultura Luiz de Queiroz, Piracicaba, SP: ESALQ, 2003.

MENON, J., DIXON, P. B. Measures of Intra-industry trade as indicators of Factor Market Disruption. Center of Policy Studies and the Impact Project. General Paper. n. G- 113, p.2-5, abr-1995. 
Ministério das Relações Exteriores (MRE). BRICS: Comércio Exterior. 2014. Disponível em: <http://www.brasilglobalnet.gov.br/ARQUIVOS/IndicadoresEconomicos /ComExtBRICS.pdf>. Acesso em: 10/06/2017.

Ministério do Desenvolvimento, Indústria e Comércio Exterior (MDIC). Balança Comercial Brasileira: dados consolidados. 2014. Disponível em: <http:// www.desenvolvimento.gov.br/>. Acesso em: 10/06/2017.

MoRAVCIK, A. Preferences and Power in the European Community: A Liberal Intergovernmentalist Approach. Journal of Common Market Studies. Vol. 31, no 4., dez/.1993, p. 473-524.

MOREIRA, U. Teorias do comércio internacional: um debate sobre a relação entre crescimento econômico e inserção externa. Revista de Economia Política, vol. 32, no 2 (127), pp. 213-228, abril-junho/2012.

OLIVER STUENKEL. BRICS e o futuro da ordem global. Editora Paz e Terra; Edição: 1. 351 p., 2017.

Palácio do Planalto. Mercosul é principal fonte de superávit comercial do Brasil. Diponível em <http://www2.planalto.gov.br/noticias/2015/07/mercosul-e-principal-fonte-desuperavit-comercial-do-brasil>. Acesso em: 10 abr. 2018.

PITON GL. Caracterização do Setor de Papel e Celulose no Período Recente. Dissertação (Mestrado em Economia). 130 f. Universidade Estadual de Campinas, Campinas, São Paulo, 2015.

POYRY TECNOLOGIA LTDA. Guia ABTCP - Fornecedores e Fabricantes. Celulose e papel 2016 /2017. Disponível em:

<http://www.poyry.com.br/sites/www.poyry.com.br/files/media/related_material/16out27aabtcp.pdf>. Acesso em: 20/08/2017.

PROGRAMA DAS NAÇÕES UNIDAS PARA O DESENVOLVIMENTO - PNUD. IDH Global. 2015. Disponível em :

<http://www.br.undp.org/content/brazil/pt/home/idh0/rankings/idh-global.html>. Acesso em: 10/02/2017.

RICHARD, Y. Intégration régionale, régionalisation, régionalisme - les mots et les choses, n 20, 2014. Disponível em <http://journals.openedition.org/confins/8939>. Acesso em 20 mar. 2018.

REIS, R. S. Economia Internacional: Vantagens Absolutas e Comparativas. 2008. Disponível em: <https://pt.scribd.com/doc/76653617/Vantagens-Absolutas-eComparativas>. Acesso em: 10/03/2017.

SALLES, T. T.; SILVA, M. L. da; SOARES, N. S. ; MORAES, A. C. de. Exportação brasileira de papel e celulose: sua dinâmica pela equação gravitacional. Rev. Árvore. 2011, vol.35, n.3, pp.573-580.

RICARDO, D. The Principles of Political Economy and Taxations. Londres: Cambridge University, 1817, $120 \mathrm{p}$.

SILVA, F. Noções do Comércio Exterior. Disponível em $<$ http://eadgrad.unigran.br/webaulas/grad_22010/administracao/nocoes_comercio_exterior /arquivos/aula09.pdf>. Acesso em: 02 set. de 2016. 
SMITH A. The Wealth of Nations. Nova York: Modern Library, 1937.

Trending Economics. Indicators. Disponível em: <https://tradingeconomics.com/>. Acesso em: 20/03/2017.

THOMPSON, W. The Regional Subsystem: A Conceptual Explication and Propositional Inventory. International Studies Quarterly, vol. 17, n¹, 1973, p. 89-117.

YEATS AJ. Does Mercosur's trade performance justify concerns about the effects of regional trade arrangements? Policy Research Working Paper, The World Bank, $n$. 1729, 1997.

\section{NOTAS DE AUTOR}

\section{CONTRIBUIÇÃO DE AUTORIA}

Letícia Soares Viana - Coleta de dados, Análise de dados, Elaboração do manuscrito Naisy Silva Soares - Concepção, orientação da primeira autora, discussão dos resultados, revisão do manuscrito

Lyvia Julienne Sousa Rego - Discussão dos resultados, revisão do manuscrito

\section{FINANCIAMENTO}

Fundação de Amparo à Pesquisa do Estado da Bahia (FAPESB) e Universidade Estadual de Santa Cruz (UESC)

\section{CONSENTIMENTO DE USO DE IMAGEM}

Não se aplica

\section{APROVAÇÃO DE COMITÊ DE ÉTICA EM PESQUISA}

Não se aplica.

\section{CONFLITO DE INTERESSES}

Não há conflito de interesses no presente artigo.

\section{LICENCCA DE USO}

Este artigo está licenciado sob a Licença Creative Commons CC-BY. Com essa licença você pode compartilhar, adaptar, criar para qualquer fim, desde que atribua a autoria da obra.

\section{HISTÓRICO}

Recebido em: 03-07-2020

Aprovado em: 15-04-2021 